TITLE:

\title{
Monitoring of duplex and triplex formation by 19F NMR using oligodeoxynucleotides possessing 5-fluorodeoxyuridine unit as 19F signal transmitter.
}

\section{$\operatorname{AUTHOR(S):~}$}

Tanabe, Kazuhito; Sugiura, Masaaki; Nishimoto, Sei-ichi

\section{CITATION:}

Tanabe, Kazuhito ...[et al]. Monitoring of duplex and triplex formation by 19F NMR using oligodeoxynucleotides possessing 5-fluorodeoxyuridine unit as 19F signal transmitter.. Bioorganic \& medicinal chemistry 2010, 18(18): 6690-6694

\section{ISSUE DATE:}

2010-09-15

URL:

http://hdl.handle.net/2433/131817

\section{RIGHT:}

(C) 2010 Elsevier Ltd; This is not the published version. Please cite only the published version.; この論文は出版社版でありません。引用の際に は出版社版をご確認ご利用ください。 


\section{Monitoring of duplex and triplex formation by ${ }^{19}$ F NMR using}

\section{oligodeoxynucleotides possessing 5-fluorodeoxyuridine unit as ${ }^{19} \mathrm{~F}$}

\section{signal transmitter}

Kazuhito Tanabe, ${ }^{*}$ Masaaki Sugiura and Sei-ichi Nishimoto*

Department of Energy and Hydrocarbon Chemistry, Graduate School of Engineering,

Kyoto University, Katsura Campus, Nishikyo-ku, Kyoto 615-8510, Japan

*corresponding author

Phone: +81-75-383-2505 FAX: +81-75-383-2504

e-mail: tanabeka@scl.kyoto-u.ac.jp,nishimot@scl.kyoto-u.ac.jp 


\section{Abstract}

We prepared oligodeoxynucleotides (ODNs) possessing a 5-fluorodeoxyuridine (5-FU)

unit as a ${ }^{19} \mathrm{~F}$-signal transmitter, and characterized their structures including single strand,

duplex and triplex using ${ }^{19} \mathrm{~F}-\mathrm{NMR}$. The change in chemical shift induced by incorporation of 5-FU into the ODNs and the formation of higher order structures allowed monitoring of structural changes. Data from UV melting experiments and CD spectra were consistent with the spectral changes in the NMR studies. These ${ }^{19}$ F-labeled ODNs may be promising molecular probes for the identification of DNA structures in complicated biological conditions. 


\section{Introduction}

DNA changes its conformation sequence-dependently into stem-and-loop, triplex, quadruplex and cruciform as well as an ordinary duplex in response to changes in the surrounding environment to express inherent functions. ${ }^{1-3}$ Identification of higher order DNA structures is crucial for understanding their function and interactions in biological systems, and thereby a considerable number of studies have been conducted on the analysis of DNA conformation using spectrometric analysis, gel electrophoresis, X-ray structural analysis and microscope observations. ${ }^{4-7}$

NMR is one of the most validated techniques for the structural determination of various types of molecules, both small and huge. ${ }^{8-10}$ In particular, ${ }^{19} \mathrm{~F}$ NMR provides clear molecular information even under complicated biological conditions because of the high sensitivity of ${ }^{19} \mathrm{~F}$ signals (approximately $83 \%$ of the sensitivity of ${ }^{1} \mathrm{H}$ ) and the low concentration of endogenous $\mathrm{F}$ atoms. ${ }^{11-13}$ Recently, several reports have shown that ${ }^{19}$ F-labeled DNA or RNA structures could be identified by ${ }^{19} \mathrm{~F}-\mathrm{NMR}$, in which spectral changes provide details of conformational information. ${ }^{14-22}$

Here, we characterized the ${ }^{19} \mathrm{~F}$ NMR spectra of oligodeoxynucleotides (ODNs) 
possessing 5-fluorodeoxyuridine $(5-\mathrm{FU})$ as a ${ }^{19} \mathrm{~F}$ signal transmitter. We anticipated that NMR signal of ${ }^{19} \mathrm{~F}$-atom in base moiety was susceptible to the duplex and triplex formation, because base-pairing was closely-concerned with the formation of higher order structure of DNA. The NMR spectra revealed that the ${ }^{19} \mathrm{~F}$ signal from the 5 -FU unit was sensitive to its immediate environment. We observed a change in chemical shift attributable to the incorporation of 5-FU into the ODNs, and the hybridization of an ODN with its complementary ODN to form duplex and triplex. Thus, we could monitor conformational changes using ${ }^{19}$ F NMR measurements.

\section{Results and Discussion}

The incorporation of a 5-FU unit into an ODN was conducted using the conventional phosphoramidite method. The ODNs in this study are summarized in Figure 1. We initially compared the ${ }^{19}$ F-NMR spectra of ODN 1 and a 5-FU monomer. As shown in Figure 2, ODN 1 showed a single signal at $-165.4 \mathrm{ppm}$, which is about $1.0 \mathrm{ppm}$ lower magnetic field of monomeric 5-FU. Enzymatic digestion of ODN 1 resulted in the appearance of a single new signal, which was attributed to the formation of monomeric 
5-FU. Thus, the incorporation of 5-FU into a DNA strand led to a change in the ${ }^{19} \mathrm{~F}$

chemical shift.

\section{ODN 1 5'-ATA AFC CCA TGG ATC CAT CAC TAC T-3' \\ ODN 2 5'-AGTA GTG ATG GAT CCA TGG GAT TAT-3' \\ ODN 3 5'-CCTTCCTFCTCCCTC-3' \\ ODN 4 5'-TACGGAAGGAAGAGGGAGTC -3' \\ ODN 5 5'-GACTCCCTCTTCCTTCCGTA-3'}

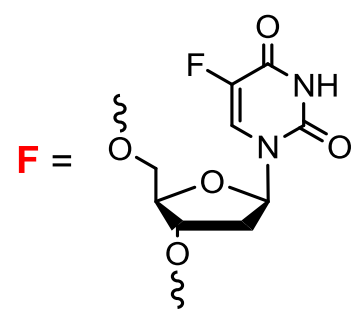

Figure 1. Sequences and structure of oligodeoxynucleotides used in this study. Triplex-forming sequences are shown in italic.

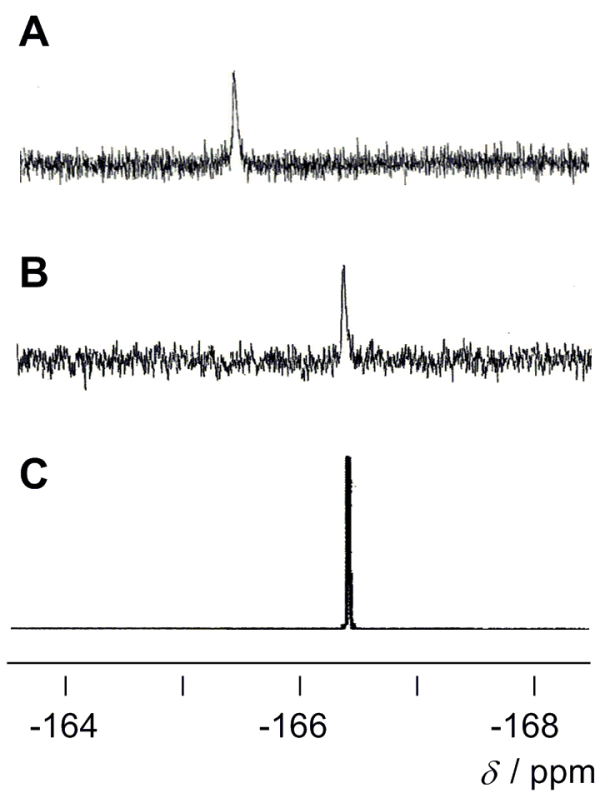

Figure 2. ${ }^{19}$ F-NMR spectra of oligodeoxynucleotides possessing 5-FU unit and monomeric 5-FU. (A) $100 \mu \mathrm{M}$ ODN 1. (B) ODN $1(100 \mu \mathrm{M})$ treated by calf intestine alkaline phosphatase $(0.02$ unit $/ \mu \mathrm{L})$, nuclease $\mathrm{P} 1(0.2 \mathrm{unit} / \mu \mathrm{L})$ and phosphodiesterase I (0.02 unit/ $\mu \mathrm{L}$ ) for $40 \mathrm{~h}$ at $37{ }^{\circ} \mathrm{C}$. (C) $62.5 \mathrm{mM}$ 5-fluorodeoxyuridine. 
We next monitored the duplex formation of ODN 1 with a complementary ODN 2 using

${ }^{19} \mathrm{~F}$ NMR (Figure 3). The addition of 0.5 eq. of ODN 2 to ODN 1 resulted in the appearance of a new signal at $-165.7 \mathrm{ppm}$. The signal intensity increased on further addition of ODN 2, up to a concentration of 1 eq., while the original signal of the single stranded ODN 1 disappeared almost completely (Figure 3C). The formation of a duplex consisting of ODN 1 and ODN 2 in an aqueous solution was confirmed by the measurement of the thermal denaturation profiles and CD spectra. In a UV melting experiment (Figure 4A), ODN 1 in the presence of ODN 2 showed a sigmoidal curve $\left(T_{\mathrm{m}}=54.8{ }^{\circ} \mathrm{C}\right)$, which was attributed to the dissociation of the duplex into a single strand. In the CD spectra (Figure 4C), we observed a positive peak at $272 \mathrm{~nm}$ and a negative peak at $242 \mathrm{~nm}$. These results strongly indicate that the new signal at -165.7 ppm in the ${ }^{19} \mathrm{~F}$-NMR spectra was attributable to the 5-FU unit in the duplex, which was retained as a B-form. ${ }^{1}$ We also confirmed that NMR measurements of an ODN 1/ ODN 2 duplex at $65{ }^{\circ} \mathrm{C}$ (Figure 3D) showed a single signal that was attributable to single stranded ODN 1 (Figure 3E), which had been formed by dissociation of the duplex. 

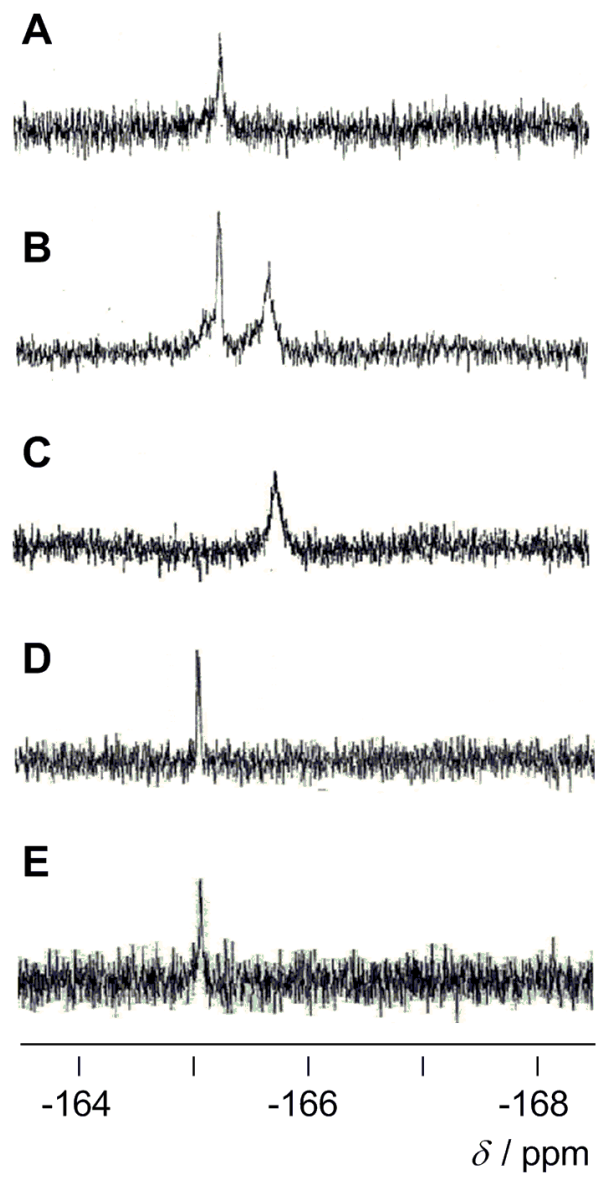

Figure 3. ${ }^{19}$ F-NMR spectra of oligodeoxynucleotides possessing 5-FU unit in $10 \mathrm{mM}$ phosphate buffer (pH 7.0) containing $10 \mathrm{mM} \mathrm{NaCl}$. (A) ODN $1(242 \mu \mathrm{M})$ at $25^{\circ} \mathrm{C}$. (B) ODN $1(216 \mu \mathrm{M})$ and ODN $2(108 \mu \mathrm{M})$ at $25^{\circ} \mathrm{C}$. (C) ODN $1(216 \mu \mathrm{M})$ and ODN 2 $(216 \mu \mathrm{M})$ at $25{ }^{\circ} \mathrm{C}$. (D) ODN $1(216 \mu \mathrm{M})$ and ODN $2(216 \mu \mathrm{M})$ at $65^{\circ} \mathrm{C}$. (E) ODN 1 $(242 \mu \mathrm{M})$ at $65^{\circ} \mathrm{C}$. 
A

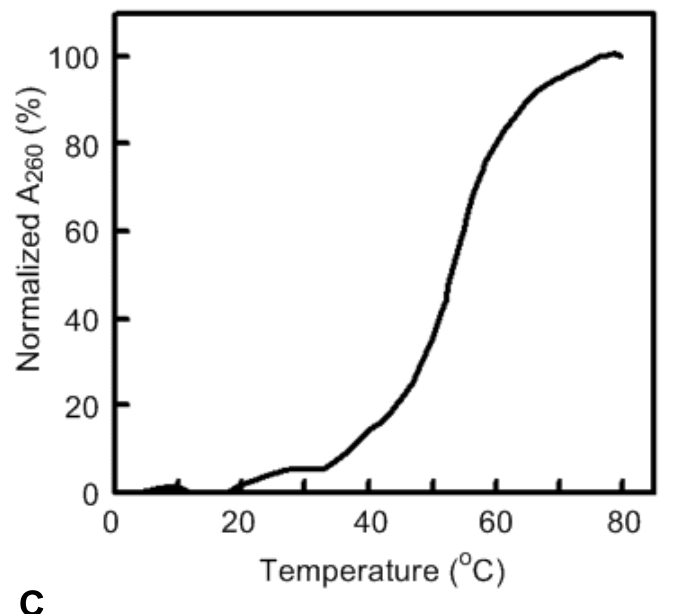

C

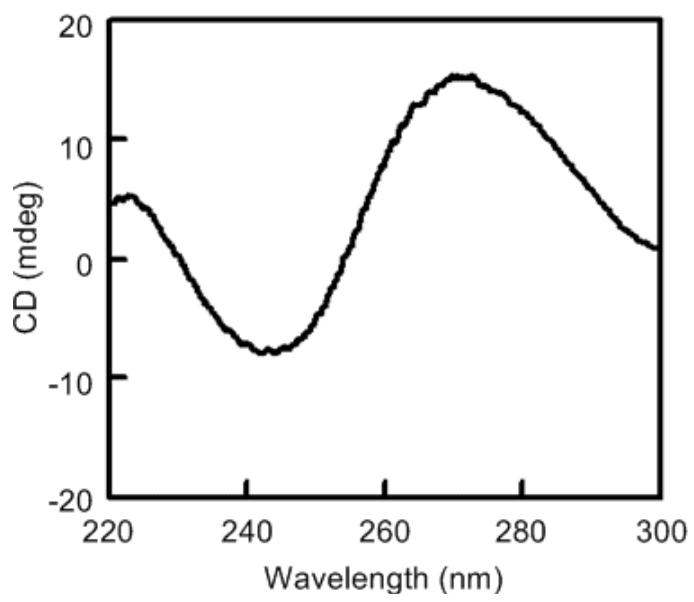

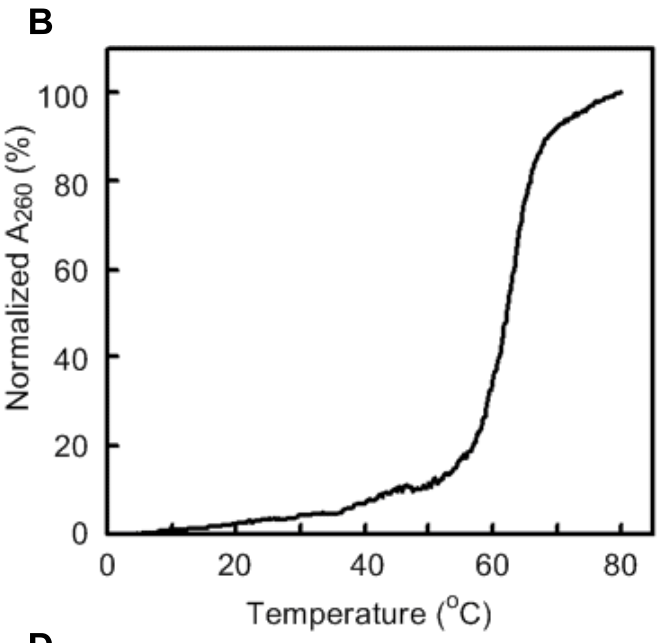

D

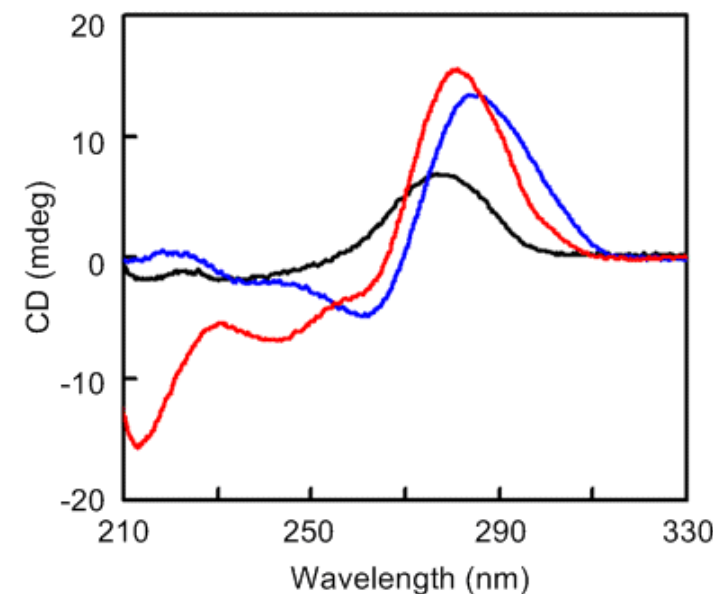

Figure 4. (A, B) UV melting curve measured at $260 \mathrm{~nm}$. (A) ODN 1/ODN 2 duplex $(2 \mu \mathrm{M})$ in $10 \mathrm{mM}$ phosphate buffer (pH 7.0) containing $10 \mathrm{mM} \mathrm{NaCl}$. (B) ODN 3/ODN 4/ODN 5 triplex in $10 \mathrm{mM}$ phosphate buffer ( $\mathrm{pH} 5.5$ ) containing $2 \mathrm{mM} \mathrm{MgCl}_{2}$. (C, D) CD spectra observed at $25^{\circ} \mathrm{C}$. (C) ODN 1/ODN 2 duplex $(2.5 \mu \mathrm{M})$ in $10 \mathrm{mM}$ phosphate buffer (pH 7.0) containing $10 \mathrm{mM} \mathrm{NaCl}$. (D) Spectra were measured in $10 \mathrm{mM}$ phosphate buffer containing $2 \mathrm{mM} \mathrm{MgCl}_{2}$. Single stranded ODN $3(2.5 \mu \mathrm{M})$ at $\mathrm{pH} 7.0$ (black). Single stranded ODN $3(2.5 \mu \mathrm{M})$ at pH 5.5 (blue). ODN 3/ODN 4/ODN 5 triplex $(2.5 \mu \mathrm{M})$ at $\mathrm{pH} 5.5$ (red). 
To monitor the change in the secondary structure of the ODNs in response to the surrounding conditions, further measurements of NMR was conducted using ${ }^{19} \mathrm{~F}$-labeled ODNs consisting of pyrimidine bases. We employed a 15 mer ODN 3 possessing a 5-FU unit in the center of its strand, and measured its ${ }^{19}$ F-NMR spectra. Figure 5 shows representative NMR spectra. At $\mathrm{pH}$ 7.0, the single stranded ODN 3 showed a single signal at $-165.7 \mathrm{ppm}$ at $25^{\circ} \mathrm{C}$, while several new signals appeared on decreasing the $\mathrm{pH}$ from 7.0 to 5.5. Elevating temperature to $50{ }^{\circ} \mathrm{C}$ at $\mathrm{pH} 5.5$ led to the appearance of new single signal, which is consistent with the signal at $\mathrm{pH} 7.0$ at $50{ }^{\circ} \mathrm{C}$, indicating that ODN 3 formed secondary structures under acidic conditions at $25{ }^{\circ} \mathrm{C}$. To confirm the higher order structure of ODN 3 at $\mathrm{pH}$ 5.5, we measured the CD spectra. As shown in Figure 4D, both a positive peak at $283 \mathrm{~nm}$ and a negative peak at $260 \mathrm{~nm}$ were observed, which are consistent with the i-motif structure bearing base pairs between protonated cytosines. $^{23,24}$ Thus, it is most likely that ODN 3 formed a higher order structure, such as i-motif under acidic conditions, but was found to melt by elevating temperatures or $\mathrm{pH}$ as monitored by ${ }^{19} \mathrm{~F}-\mathrm{NMR}$. 

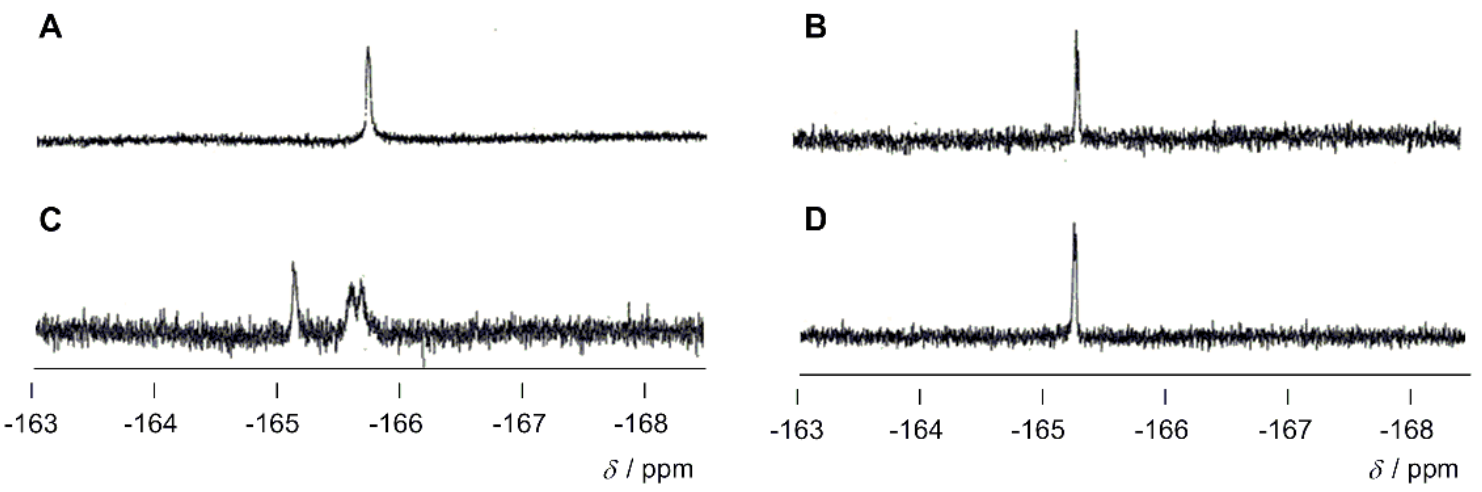

Figure 5. ${ }^{19} \mathrm{~F}-\mathrm{NMR}$ spectra of ODN $3(250 \mu \mathrm{M})$ possessing 5-FU unit in $10 \mathrm{mM}$ phosphate buffer containing $2 \mathrm{mM} \mathrm{MgCl}{ }_{2}$. (A) at $\mathrm{pH} 7.0\left(25{ }^{\circ} \mathrm{C}\right)$. (B) at $\mathrm{pH} 7.0\left(50{ }^{\circ} \mathrm{C}\right)$. (C) at pH $5.5\left(25^{\circ} \mathrm{C}\right)$. (D) at $\mathrm{pH} 5.5\left(50^{\circ} \mathrm{C}\right)$.

The association of an oligopyrimidine sequence to a DNA duplex via Hoogsteen hydrogen bonding generates DNA triplex. We next conducted NMR measurements on triplex containing ${ }^{19} \mathrm{~F}$-labeled $\mathrm{ODN} 3$ in the presence of $\mathrm{MgCl}_{2}$ at $\mathrm{pH}$ 5.5. Although ODN 3 showed several signals due to the formation of higher order structures as described above, the addition of an ODN 4/ODN 5 duplex resulted in the appearance of a new signal around -166.9 ppm (Figure 6). The CD spectra of ODN 3 after the addition of the ODN 4/ODN 5 duplex showed a negative peak around $210 \mathrm{~nm}$, which was attributed to the formation of triplex (Figure 4D) ${ }^{25}$ The melting curve showed two 
transitions at temperatures of $T_{\mathrm{m}}=42.6$ and $63.1{ }^{\circ} \mathrm{C}$ (Figure 4B), as is a typical behavior of a triplex. The evidence that the NMR of ODN 3 in the presence of an ODN 4/ODN 5 duplex at $50{ }^{\circ} \mathrm{C}$ showed the disappearance of the signal around -166.9 ppm (Figure 6D) and appearance of a signal attributable to single stranded ODN 3 (Figure 6E) indicates that the signal around $-166.9 \mathrm{ppm}$ can be assigned to the 5-FU unit in triplex. Thus, we could monitor triplex formation of ODN 3 using NMR measurements. 
A

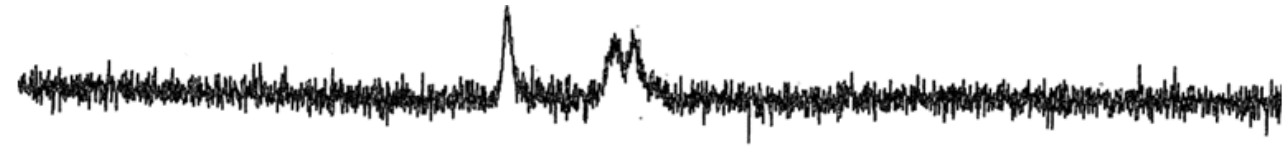

B

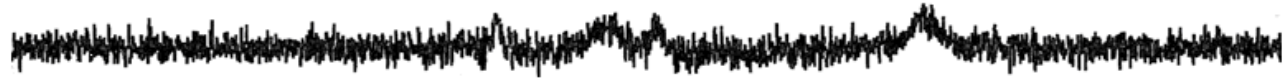

C
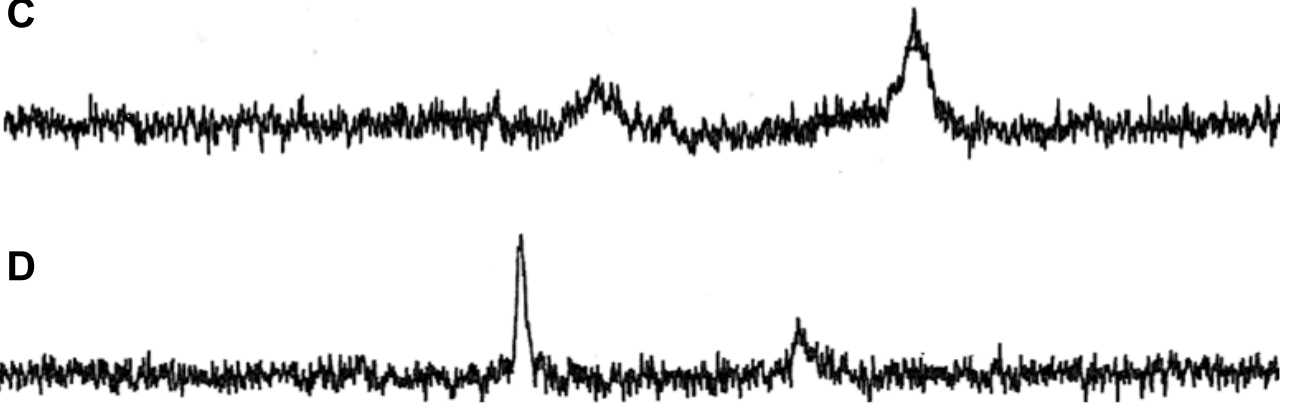

E

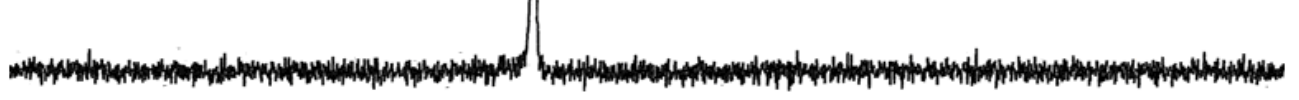

I

$-163$

$-164$

$-165$

$-167$

$-168 \quad \delta / \mathrm{ppm}$

Figure 6. ${ }^{19} \mathrm{~F}-\mathrm{NMR}$ spectra of ODN 3 possessing 5-FU unit in $10 \mathrm{mM}$ phosphate buffer (pH 5.5) containing $2 \mathrm{mM} \mathrm{MgCl}_{2}$. (A) ODN $3(250 \mu \mathrm{M})$ at $25^{\circ} \mathrm{C}$. (B) ODN $3(219 \mu \mathrm{M})$ in the presence of ODN 4/ODN 5 duplex $(219 \mu \mathrm{M})$ at $25^{\circ} \mathrm{C}$. (C) ODN $3(211 \mu \mathrm{M})$ in the presence of ODN 4/ODN 5 duplex $(296 \mu \mathrm{M})$ at $25^{\circ} \mathrm{C}$. (D) ODN $3(211 \mu \mathrm{M})$ in the presence of ODN 4/ODN 5 duplex $(296 \mu \mathrm{M})$ at $50{ }^{\circ} \mathrm{C}$. (E) single stranded ODN 3 (250 $\mu \mathrm{M})$ at $50{ }^{\circ} \mathrm{C}$. 


\section{Conclusions}

In conclusion, we characterized the structure and conformation of ODNs possessing a

${ }^{19} \mathrm{~F}$ signal transmitting unit of 5-FU using ${ }^{19} \mathrm{~F}-\mathrm{NMR}$. Throughout the chemical shift changes of the ${ }^{19} \mathrm{~F}$ signal, we could monitor the incorporation of 5-FU into an ODN, and the formation of duplex and triplex. Thus, we verified that the ${ }^{19} \mathrm{~F}$-labeled DNA used in this study could act as a molecular probe for the structural analysis of DNA. Characterization of more complicated DNA-DNA interactions and DNA-protein interaction is now in progress. 


\section{Experimental Section}

\section{General.}

The reagents for the DNA synthesis were purchased from Glen Research. Other reagents were purchased from Wako pure chemical industries, Nacalai tesque, and Aldrich, and Tokyo chemical industries, used without purification. Calf intestine alkaline phosphatase (AP), phosphodiesterase I (PDE), and Nuclease P1 (P1) were purchased from Promega, ICN, and YAMASA CO., Ltd, respectively. The ODN 2, ODN 4 and ODN 5 were purchased from Invitrogen. All aqueous solutions utilized purified water (Millipore, Milli-Q sp UF). Matrix-assisted laser desorption ionization time-of-flight (MALDI-TOF) mass spectrometry of ODNs were obtained on JEOL JMS-ELITE MALDI-TOF MASS spectrometer with 2',3',4'-trihydroxyacetophenone as the matrix (acceleration voltage $20 \mathrm{kV}$, negative ion mode), using $\mathrm{T}_{8}\left([\mathrm{M}-\mathrm{H}]^{-}\right.$ 2370.61), $\mathrm{T}_{17}\left([\mathrm{M}-\mathrm{H}]^{-}\right.$5108.37), and $\mathrm{T}_{27}\left([\mathrm{M}-\mathrm{H}]^{-}\right.$8150.33) as the internal standards. Reversed-phase HPLC were performed on a HITACHI LaChrom system using a Inertsil ODS-3 HPLC column $(10 \times 250 \mathrm{~mm}, 4.6 \times 150 \mathrm{~mm}) .{ }^{19} \mathrm{~F}$ NMR spectra was measured 
with JEOL-AL-400 (376 MHz) spectrometer. CD spectra were measured with JASCO J-805 spectroporalimeter. UV spectra were measured with JASCO V-630 UV/Vis spectrometer equipped with a temperature programmable cell block.

Synthesis of 5-FU containing ODN (ODN 1 and ODN 3). Automated synthesis was carried out by using a standard $\beta$-(cyanoethyl)phosphoramidite method with Applied Biosystems 3400 DNA synthesizer. Synthesized oligomers were deprotected and removed from the solid support by treating with concentrated ammonia at $55{ }^{\circ} \mathrm{C}$ for $3 \mathrm{~h}$. Purification of ODNs was performed on an Inertsil ODS-3 HPLC column with a linear gradient of $0-30 \%$ acetonitrile in $100 \mathrm{mM}$ triethylammonium acetate for $30 \mathrm{~min}$ at a flow rate $3.0 \mathrm{~mL} / \mathrm{min}$. The concentration of the synthesized ODNs was determined by complete digestion with PDE $(0.02 \mathrm{U} / \mu \mathrm{L}), \mathrm{AP}(0.02 \mathrm{U} / \mu \mathrm{L})$, and nuclease P1 $(0.2 \mathrm{U} / \mu \mathrm{L})$

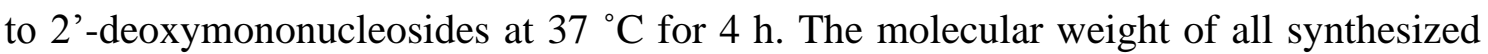
ODNs was obtained by MALDI-TOF MS: ODN 1, calcd 7547.86, found 7547.67; ODN 3, calcd 4368.72, found 4369.52. 
NMR spectroscopy. ${ }^{19}$ F-NMR spectra without ${ }^{1} \mathrm{H}$-decoupling were measured at a frequency of $376.05 \mathrm{MHz}$ and were referenced relative to external $\mathrm{CF}_{3} \mathrm{COOH}(-76.5$ ppm). Experimental parameters were as follows: ${ }^{19} \mathrm{~F}$ excitation pulse $8.00 \mu \mathrm{s}$, acquisition time $1.3 \mathrm{~s}$, relaxation delay $5 \mathrm{~s}$, number of scans ca.7000.

Melting temperature of hybridized ODNs. A $2 \mu \mathrm{M}$ solution of ODN 1/ODN 2 duplex was dissolved in $10 \mathrm{mM}$ sodium phosphate buffer ( $\mathrm{pH}$ 7.0) containing $100 \mathrm{mM} \mathrm{NaCl}$. On the other hands, $2 \mu \mathrm{M}$ solution of ODN 3/ODN 4/ODN 5 triplex was dissolved in 10 $\mathrm{mM}$ sodium phosphate buffer ( $\mathrm{pH}$ 5.5) containing $2 \mathrm{mM} \mathrm{MgCl}_{2}$. Melting curves were obtained by monitoring the absorbance at $260 \mathrm{~nm}$ with elevating temperature at a rate of $1.2{ }^{\circ} \mathrm{C} / \mathrm{min}$ from $4{ }^{\circ} \mathrm{C}$ to $90{ }^{\circ} \mathrm{C}$.

CD spectra. Similar to the experiments for $T_{\mathrm{m}}$ measurements, aqueous solution of ODNs were prepared. CD spectra of the solution were recorded using UV cell with 1 cm path length. 


\section{References and notes}

1. Saenger, W. Principles of Nucleic Acid Structure; Springer-Verlag: New York, 1984.

2. Sinden, R. R. DNA Structure and Function; Academic Press: New York, 1994.

3. Cozzarelli, N. R.; Wang, J. C. DNA Topology and Its Biological Effects; Cold Spring Harbor Laboratory Press: New York, 1990.

4. Brown, T. A. Genomes; Garland Science: New York, 2007.

5. Watson, J. D.; Hopkins, N. H.; Roberts, J. W.; Steitz, J. A.; Weiner, A. M. Molecular Biology of the Gene; Peason/Benjamin Cummings: San Francisco, 2008.

6. Rothemund, P. W. K. Nature 2006, 440, 297.

7. Endo, M.; Sugiyama, H. ChemBioChem. 2009, 10, 2420.

8. Zídek, L.; Štefl, R.; Sklenář, V. Curr. Opin. Struct. Biol. 2001, 11, 275.

9. Fürtig, B.; Richter, C.; Wöhnert, J, Schwalbe, H. ChemBioChem. 2003, 4, 936.

10. Mayer, M.; James, T. L. Methods Enzymol. 2005, 394, 571.

11. Tanabe, K.; Harada, H.; Narazaki, M.; Tanaka, K.; Inafuku, K.; Komatsu, H.; Ito, T.; Yamada, H.; Chujo, Y.; Matsuda, T.; Hiraoka, M.; Nishimoto, S. J. Am. Chem. Soc. 2009, 131, 15982.

12. Greig, J. T. In Biological Magnetic Resonance; Berliner, L.; Reuben, J., Eds.; Plenum Press: New York, 1978; p 139.

13. Rastinejad, F.; Evilia, C.; Lu, P. Methods Enzymol. 1995, 261, 560.

14. Kreutz, C.; Kählig, H.; Konrat, R.; Micura, R. J. Am. Chem. Soc. 2005, 127, 1158.

15. Olsen, G. L.; Edwards, T. E.; Deka, P.; Varani, G.; Sigurdsson, S. Th.; Drobny, G. P. Nucleic Acids Res. 2005, 33, 3447.

16. Hennig, M.; Munzárova, M. L.; Bermel, W.; Scott, L. G.; Sklenár, V.; Williamson, J. R. J. Am. Chem. Soc. 2006, 128, 5851.

17. Kreutz, C.; Kählig, H.; Konrat, R.; Micura, R. Angew. Chem. Int. Ed. 2006, 45, 3450 .

18. Hennig, M.; Scott, L. G.; Sperling, E.; Bermel, W.; Williamson, J. R. J. Am. Chem. Soc. 2007, 129, 14911.

19. Barhate, N. B.; Barhate, R. N.; Cekan, P.; Drobny, G.; Sigurdsson, S. Org. Lett. 
2008, 10, 2745.

20. Graber, D.; Moroder, H.; Micura, R. J. Am. Chem. Soc. 2008, 130, 17230.

21. Puffer, B.; Kreutz, C.; Rieder, U.; Ebert, M. -O.; Konrat, R.; Micura, R. Nucleic Acids Res. 2009, 37, 7728.

22. Kiviniemi, A.; Virta, P. J. Am. Chem. Soc. ASAP.

23. Seela, F.; Budow, S.; Leonard, P. Org. Biomol. Chem. 2007, 5, 1858.

24. Manzini, G.; Yathindra, N.; Xodo, L. E. Nucleic Acids Res. 1994, 22, 4634.

25. Kan, Y.; Schuster, G. B. J. Am. Chem. Soc. 1999, 121, 11607. 